\title{
Review
}

\section{Molecular markers in prostate cancer. Part I: predicting lethality}

\author{
Sachin Agrawal, William D. Dunsmuir \\ Department of Urology, St. Peters Hospital, Chertsey KT160PZ, UK
}

\begin{abstract}
Assessing the lethality of 'early,' potentially organ-confined prostate cancer (PCa) is one of the central controversies in modern-day urological clinical practice. Such cases are often considered for radical 'curative' treatment, although active surveillance may be equally appropriate for many men. Moreover, the balance between judicious intervention and overtreatment can be difficult to judge. The patient's age, comorbidities, family history and philosophy of self-health care can be weighed against clinical features such as the palpability of disease, the number and percentage of biopsy cores involved with the disease, histological grade, presenting prostate-specific antigen (PSA) and possible previous PSA kinetics. For many years, scientists and physicians have sought additional molecular factors that may be predictive for disease stage, progression and lethality. Usually, claims for a 'new' unique marker fall short of true clinical value. More often than not, such molecular markers are useful only in multivariate models. This review summarizes relevant molecular markers and models reported up to and including 2008.
\end{abstract}

Asian Journal of Andrology (2009) 11: 14-21. doi: 10.1038/aja.2008.20; published online 1 December 2008.

Keywords: genetics, neoplasm metastasis, prostate cancer

\section{Introduction}

Current ideological frameworks for the pathogenesis of prostate cancer (Pca) emphasize the roles of precursor lesions such as prostatic intraepithelial neoplasia (PIN), proliferative inflammatory atrophy (PIA) and tissue hypoxia. Alternative theories suggest that prostate stem cells function as reservoirs of disease. Research has focused on identifying potential molecular and genetic markers, which may help to clarify and predict the natural history of PCa: thus helping to identify those suitable for active surveillance [1]. A number of potential diagnostic, prognostic and surveillance markers have been identified [2-46] (Table 1).

Developments in molecular technology have helped to

Correspondence to: Mr Sachin Agrawal, Department of Urology, St. Peters Hospital, Chertsey KT16 0PZ, UK.

Tel: +44-19-3272-2640 E-mail: agrawalsachin@hotmail.com

Received: 29 September 2008 Accepted: 2 October 2008

Published online: 1 December 2008 identify and alter the expression of these genes and the related markers. Techniques such as fluorescence-activated cell sorting, fluorescence in situ hybridization, reverse transcription polymerase chain reaction and proteomics have improved sensitivity, facilitating the detection of smaller groups of prostate cells and markers. The identification of many markers still relies on tissue sampling, which is invasive and susceptible to sampling error. Urine and serum samples are safer, more acceptable alternatives and have been analysed using deoxyribonucleic acid (DNA)/ribonucleic acid (RNA)-based assays. However, urine and serum samples may have lower sensitivities because early well-differentiated PCa is less likely to be present [21]. In metastatic $\mathrm{PCa},>5$ cells per $7.5 \mathrm{~mL}$ of blood are detectable, setting a minimum target for molecular assays [20]. The role of seminal plasma as a rich source of markers has also been reviewed, but limited studies exist because of difficulties in sampling and tolerance [21]. Difficulties in obtaining sufficient amounts of high-quality ribonucleic acid for microarrays have also 


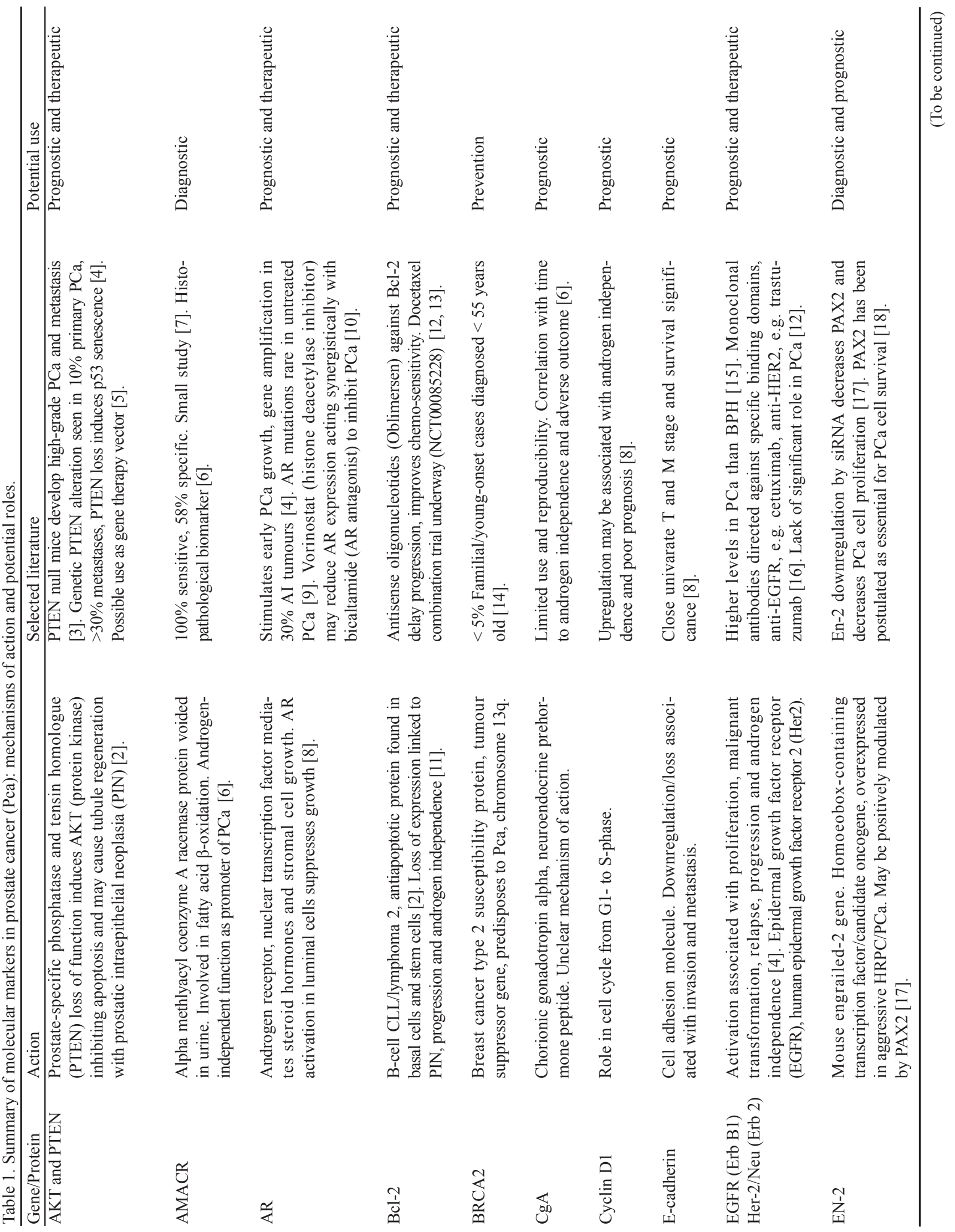




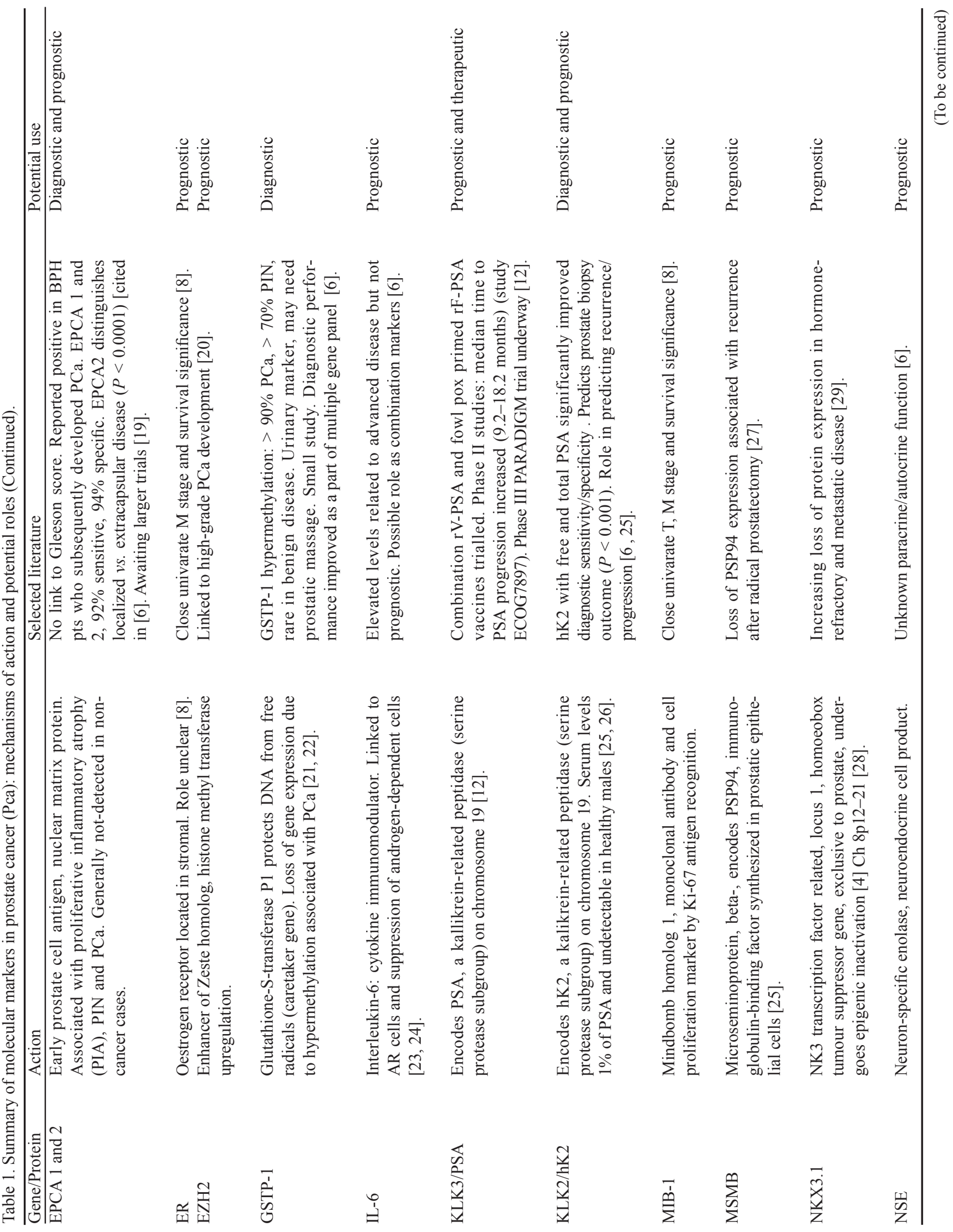



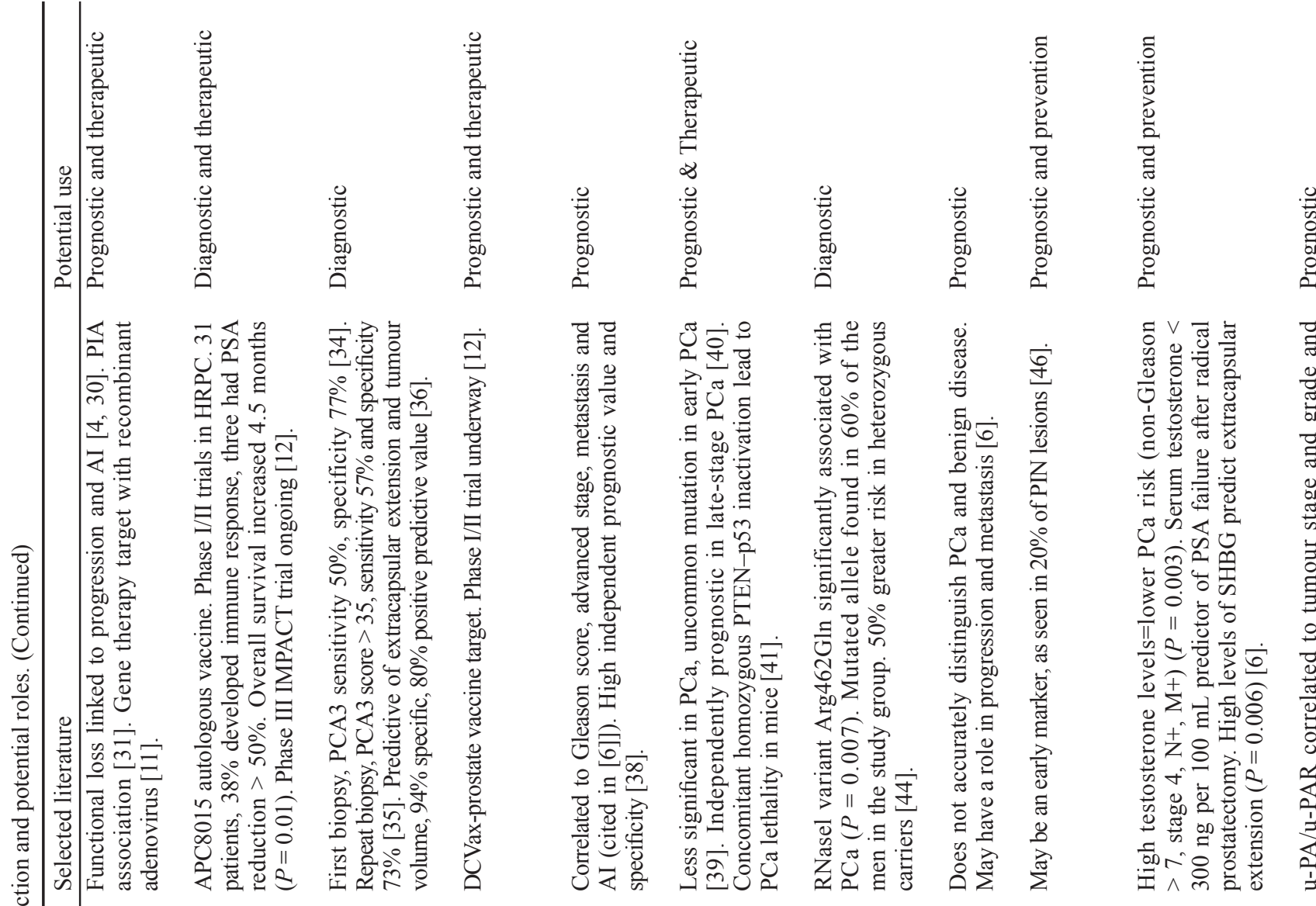

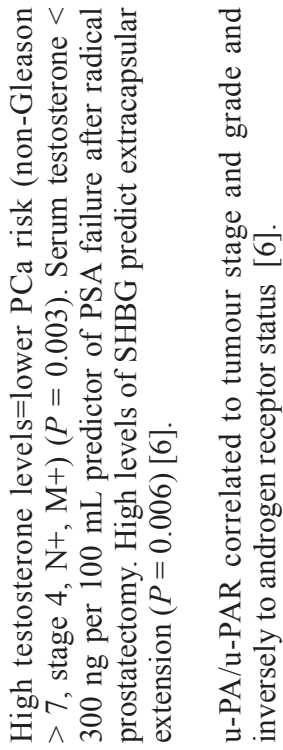

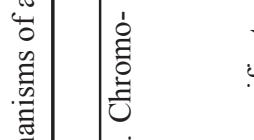

0
0
0
0
0
0
0
0
0
0
0
0
0
0
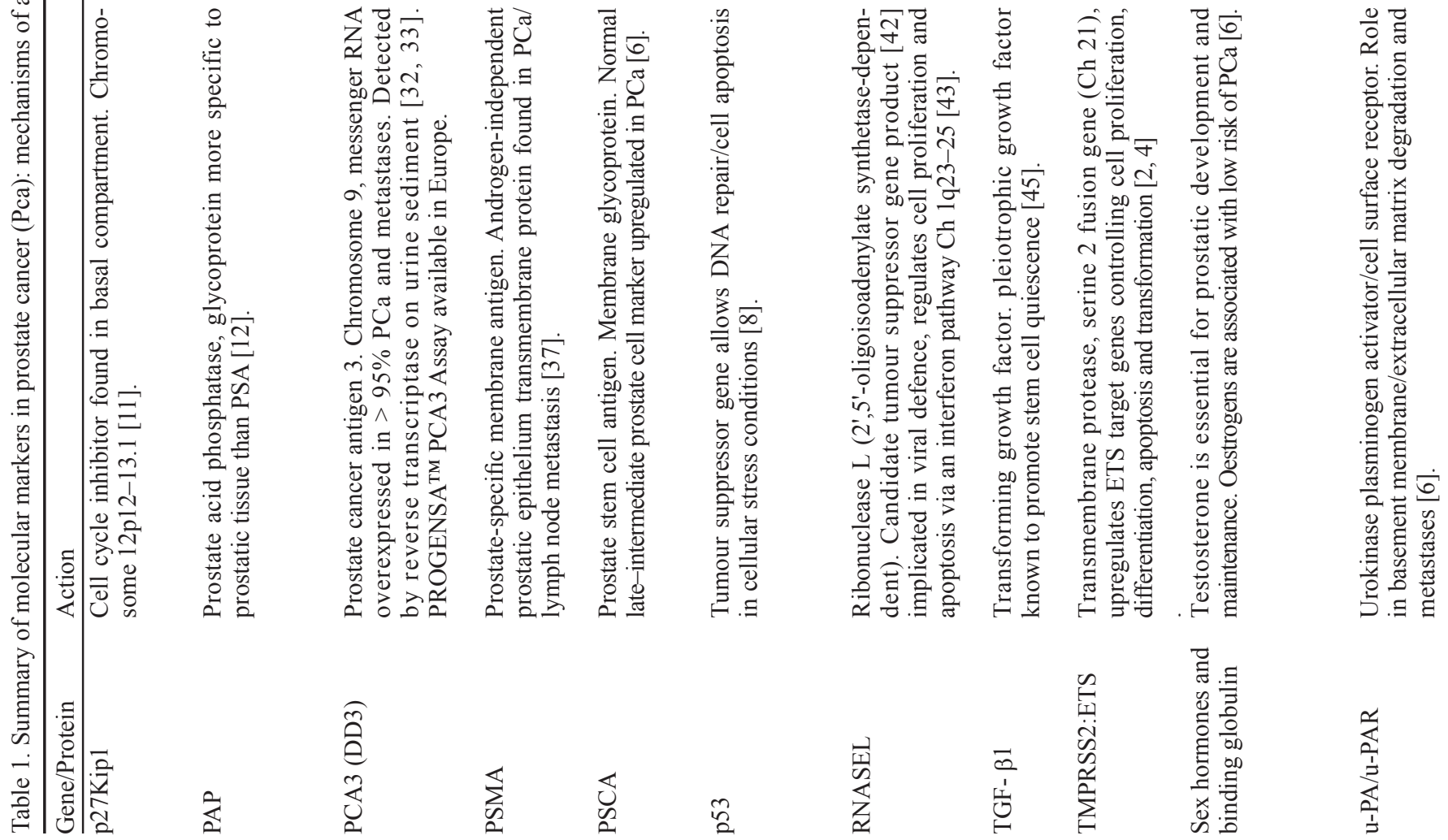

อิ

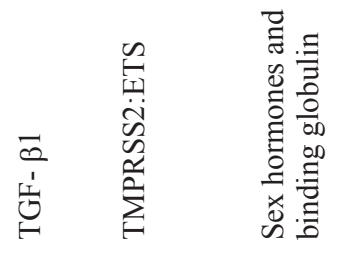

$\frac{2}{2}$ 
been overcome $[16,47]$. Notably, multiple marker arrays may also improve detection; Glutathione-S-transferase P1 (GSTP-1) has been used in a four-gene panel (p16/ARF/ MGMT/GSTP-1) in 52 PCa patients, resulting in $87 \%$ sensitivity and $100 \%$ specificity. These data need to be reproduced in large-scale randomized studies [48].

\section{Genetics}

Familial and epidemiological studies have supported the concept of a genetic predisposition to $\mathrm{PCa}$ and have helped to clarify susceptible loci [14, 28, 49, 50]. Some studies have focused on specific groups such as Ashkenazi Jews, but to date no single gene has reproducibly been found to be responsible for $\mathrm{PCa}$, reflecting the multifocal and heterogenic nature of $\mathrm{PCa}[4,51]$. Familial studies have shown the relative risks of $\mathrm{PCa}$ to be 2.0 and 1.7 in first- and second-degree relatives, respectively, with the risk increasing to 8.8 when first- and second-degree relatives are both afflicted $[49,52]$. A recent genome-wide association study identified several loci (chromosomes 3, 6, 7, 10, 11, 19 and X) associated with PCa [25]. The previously known 8q24 and17q loci were also confirmed, along with the identification of three new candidate susceptibility genes (MSMB, LMTK2, KLK3) [25]. Several groups have identified links to other loci; however, reproducibility between data sets has been limited. Nonetheless, common loci have been found on chromosomes 1, 8p12-22, 17, 19 and 22 [4, 50]. Genetic changes in PIN have also been identified and implicated in PCa pathogenesis, with 8p1222 loss of heterozygosity seen in $63 \%$ of PIN lesions [53]. Viral DNA expression upon genomic screening of $\mathrm{PCa}$ specimens has also been reported [54].

\section{Proteomics}

Current research has focused on the mass identification of proteins. Proteomics has resulted in the ability to rapidly process large numbers of clinical samples, potentially deeming it to be a highly sensitive diagnostic, surveillance and prognostic tool [55]. Proteomics uses surface-enhanced laser desorption/ionization time-of-flight mass spectrometry with selective primed surface arrays [55]. Notably, proteomic pattern analysis has correctly identified up to $95 \%$ of PCa and $78 \%$ of benign samples [56]. Prostate biopsies could thus be avoided in men with PSA ranges from 2.5 to $15 \mathrm{ng} \mathrm{mL}^{-1}$ without missing any instances of PCa [57]. Nonetheless, several problems need to be overcome, including artefacts, sample errors, storage and collection techniques; proteomic profiles may vary at different stages of $\mathrm{PCa}$, resulting in inconsistency [55].

\section{Hypoxia, PIA and PIN}

One proposed mechanism for prostate carcinogenesis is that genomic DNA may undergo genotoxic stress such as occurs in hypoxia or inflammation. This may occur under normal cellular conditions or secondary to external insults, resulting in activation of cellular checkpoint cascades capable of repair, cell-cycle arrest or apoptosis [4]. Abnormalities in this control mechanism have been implicated in progression to $\mathrm{PCa}$, including defects in the p53 response and lack of DNA damage checkpoint enforcement by Wee1A (a G2/ $\mathrm{M}$ regulator) $[58,59]$.

Tissue hypoxia is detectable in $30 \%-90 \%$ of $\mathrm{PCa}$ samples, and its role in $\mathrm{PCa}$ microenvironments has been reviewed [60]. Hypoxia may arise when tumour growth surpasses the vascular supply provided by angiogenic growth, and it has been implicated as a prognostic factor linked to androgen independence and chemo/radiotherapy resistance. Hypoxia may alter cell-cycle checkpoints and DNA repair (leading to genetic instability), up-regulate VEGF/HIF-1 expression (promoting angiogenesis and metastasis) and reduce apoptosis through p53-mutated cells [60]. Studies have also shown that antiandrogens improve tissue oxygenation by reducing angiogenesis [60].

PIN and PIA are found in PCa specimens and are thought to be precursor lesions, with PIA found to merge with areas of PIN [61]. PIA is postulated as a link between prostatitis and PIN and is common in the peripheral zone of the prostate [62]. A number of studies support the theory of PIA as a PCa precursor. The odds ratio of $\mathrm{PCa}$ in prostatitis is 1.7 , with a relative risk of 2.5 for bacterial prostatitis [63]. PIA is thought to be a regenerative lesion associated with a low apoptotic rate and elevated Bcl-2 expression [31]. Another study has detected bacterial DNA sequences in $19.6 \%$ of patients with PCa [64]. Inflammation is thought to produce free radicals and oxidative stress, inducing protein, tissue and vascular damage leading to PIA. Anti-inflammatory agents are associated with $\mathrm{a}>50 \%$ reduction in $\mathrm{PCa}$ risk, and COX-2 inhibitors have been shown to slow progression and recurrence of $\mathrm{PCa}$ [12]. Presently, COX-2 inhibitors have been withdrawn from the market owing to cardiovascular side effects. Other antiinflammatory agents, such as epigallocatechin-3-gallate found in green tea, may also play a chemo-preventive role [65]. These observations suggest potential genetic targets for prevention and treatment. Potential markers involved in the susceptibility of the prostate to infection include macrophage scavenger receptor 1, TOLL-like receptor-4 and 2'5'-oligoadenylate-dependent RNasel (RNasel) and the loss of glutathione S-transferase (a detoxifying enzyme linked to genomic instability and damage) [43].

\section{$5 \quad$ Stem cells}

The cancer stem cell theory, which proposes that PCa 
originates from prostate stem cells (PSCs), was first suggested in 1875, supported by work in the 1960s $[19,66]$. This theory is supported by recent observations. In acute myelogenous leukaemia, only minor subpopulations of cells have been shown to be capable of self-renewal, disease initiation and propagation when transplanted into immune-deficient mice [67]. Clonality has also shown the ability of these cells to differentiate into the various original leukaemic cells. In the prostate, cyclical atrophy and regeneration of rodent prostate glands with intermittent androgen deprivation have been described, showing the capacity for self-renewal and suggesting the presence of PSCs [2]. In addition to these PSCs being androgen independent, cancer stem cells have been shown to be relatively chemo/radiotherapy insensitive, hence acting as a possible reservoir for recurrent and androgen-independent (hormone-resistant PCa [HRPC]) disease [20, 68, 69]. Four cellular types exist within the prostate, which are identifiable by specific markers (basal cells, transient amplifying cells, luminal and neuroendocrine cells) [4]. PSCs are hypothesized to reside in the basal cell layer and may produce intermediate transient amplifying cells, which exhibit both luminal and basal cell markers. The neuroendocrine cell lineage is still unknown, but may arise from PSCs $[2,70]$. Previous studies cited by the authors support this concept owing to the absence of a prostate in mice null for basal layer marker p63. Stem cell markers have also been identified in human and murine prostatic epithelial cells (Sca-1, CD133, $\alpha 2 \beta 1$, integrin, CD44, Oct4, Nanog, breast cancer resistance protein and SOX2) $[4,19,20])$. PSC research is in its infancy, with stem cell culture reported to be demanding, relatively unproductive and subject to variation in different environments/culture media [71]. PSCs are also rare in circulating blood, and adequate sampling requires biopsy or bone marrow aspiration [20]. However, therapies directed at selectively targeting PSC surface markers and their signalling pathways may offer a novel and highly specific treatment approach to PCa. The challenge will be to ensure tissue and organ specificity. Finally, Hedgehog pathway inhibitors have been shown to halt growth of PCa in murine models [2].

\section{Conclusion}

The genetic and molecular basis of $\mathrm{PCa}$ is complex; however, technological advances have increased our knowledge in this field. The identification of multiple genetic and biological markers has reinforced the concept of a 'multi-hit theory' for $\mathrm{PCa}$, with some patients being genetically predisposed. Other genetic loci may only be altered under specific dietary or environmental conditions. Bacterial and viral infectious triggers may also be involved. PSA is the current mainstay for diagnosis and prognosis, but has a sensitivity of $20 \%$ and a specificity of $80 \%$ (PSA range, $4-10 \mathrm{ng} \mathrm{mL}^{-1}$ ) [72]. Biomarkers for risk stratification, prediction of invasion and metastases are emerging, with multiple marker assays potentially offering improved diagnostic benefits. New markers such as PCA3, AMACR, EPCA, GSTP1, RNASEL and hK2 offer the potential to improve sensitivity and specificity, with some now having achieved commercial and clinical acceptance.

\section{References}

1 Parker C. Active surveillance: towards a new paradigm in the management of early prostate cancer. Lancet Oncol 2004; 5: $101-6$.

2 Lawson DA, Witte ON. Stem cells in prostate cancer initiation and progression. J Clin Invest 2007; 117: 2044-50.

3 Wang S, Gao J, Lei Q, Rozengurt N, Pritchard C, et al. Prostatespecific deletion of the murine Pten tumor suppressor gene leads to metastatic prostate cancer. Cancer Cell 2003; 4: 209-21.

4 Hällström TM, Laiho M. Genetic changes and DNA damage responses in the prostate. Prostate 2008; 68: 902-18.

5 Vaughn DJ, Brown AW Jr, Harker WG, Huh S, Miller L, et al. Multicenter Phase II study of estramustine phosphate plus weekly paclitaxel in patients with androgen-independent prostate carcinoma. Cancer 2004; 100: 746-50.

6 Ramírez ML, Nelson EC, Evans CP. Beyond prostate-specific antigen: alternate serum markers. Prostate Cancer Prostatic Dis 2008; 11: 216-29.

7 Rogers CG, Yan G, Zha S, Gonzalgo ML, Isaacs WB, et al. Prostate cancer detection on urinalysis for alpha methylacyl coenzyme, a racemase protein. J Urol 2004; 172: 1501-3.

8 Dunsmuir WD, Gillett CE, Meyer LC, Young MP, Corbishley $\mathrm{C}$, et al. Molecular markers for predicting prostate cancer stage and survival. BJU Int 2000; 86: 869-78.

9 Culig Z, Klocker H, Bartsch G, Hobisch A. Androgen receptor mutations in carcinoma of the prostate: significance for endocrine therapy. Am J Pharmacogenom 2001; 1: 241-9.

10 Marrocco DL, Tilley WD, Bianco-Miotto T, Evdokiou A, Scher $\mathrm{HI}$, et al. Suberoylanilide hydroxamic acid (vorinostat) represses androgen receptor expression and acts synergistically with an androgen receptor antagonist to inhibit prostate cancer cell proliferation. Mol Cancer Ther 2007; 6: 51-60.

11 Hussain A, Dawson NA. Chemotherapy in hormone resistant prostate cancer. In: Basow DS, editor. UpToDate Waltham, MA: UpToDate; 2008.

12 Moon C, Park JC, Chae YK, Yun JH, Kim S. Current status of experimental therapeutics for prostate cancer. Cancer Lett 2008; 266: 116-34.

13 Walczak JR, Pili R, Carducci MA. Novel and emerging treatment techniques in prostate cancer. In: Basow DS, editor. UpToDate. Waltham, MA: UpToDate; 2008.

14 Edwards SM, Eeles RA. Unravelling the genetics of prostate cancer. Am J Med Genet C Semin Med Genet 2004; 129C: 65-73.

15 De Miguel P, Royuela M, Bethencourt R, Ruiz A, Fraile B, et al. Immunohistochemical comparative analysis of transforming growth factor alpha, epidermal growth factor and epidermal growth factor receptor in normal, hyperplastic and neoplastic human prostates. Cytokine 1999; 11: 722-7. 
16 Golias Ch, Charalabopoulos A, Stagikas D, Giannakopoulos X, Peschos D, et al. Molecular profiling and genomic microarrays in prostate cancer. Exp Oncol 2007; 29: 82-4.

17 Bose SK, Bullard RS, Donald CD, Oncogenic role of Engrailed-2 (En-2) in prostate cancer cell growth and survival. Translat Oncogenom 2008; 2: 37-43.

18 Gibson W, Green A, Bullard RS, Eaddy AC, Donald CD. Inhibition of PAX2 expression results in alternate cell death pathways in prostate cancer cells differing in p 53 status. Cancer Lett 2007; 248: 251-61.

19 Kasper S. Stem cells: The root of prostate cancer? J Cell Physiol 2008; 216: 332-6.

20 Maitland NJ, Collins AT. Prostate cancer stem cells: a new target for therapy. J Clin Oncol 2008; 26: 2862-70.

21 Schiffer E. Biomarkers for prostate cancer. World J Urol 2007; 25: 557-62.

22 Harden SV, Guo Z, Epstein JI, Sidransky D. Quantitative GSTP1 methylation clearly distinguishes benign prostatic tissue and limited prostate adenocarcinoma. J Urol 2003; 169: 1138-42.

23 Giri D, Ozen M, Ittmann M. Interleukin-6 is an autocrine growth factor in human prostate cancer. Am J Pathol 2001; 159: 2159-65.

24 Lee SO, Lou W, Hou M, de Miguel F, Gerber L, et al. Interleukin-6 promotes androgen-independent growth in $\mathrm{LNCaP}$ human prostate cancer cells. Clin Cancer Res 2003; 9: 370-6.

25 Eeles RA, Kote-Jarai Z, Giles GG, Olama AA, Guy M, et al. UK Genetic Prostate Cancer Study Collaborators; British Association of Urological Surgeons' Section of Oncology; UK ProtecT Study Collaborators, Horwich A, Huddart RA, Khoo VS, Parker CC, Woodhouse CJ, et al. editors. Multiple newly identified loci associated with prostate cancer susceptibility. Nat Genet 2008; 40: 316-21.

26 Becker C, Piironen T, Pettersson K, Björk T, Wojno KJ, et al. Discrimination of men with prostate cancer from those with benign disease by measurements of human glandular kallikrein 2 (HK2) in serum. J Urol 2000; 163: 311-6.

27 Reeves JR, Dulude H, Panchal C, Daigneault L, Ramnani DM. Prognostic value of prostate secretory protein of 94 amino acids and its binding protein after radical prostatectomy. Clin Cancer Res 2006; 12: 6018-22.

28 Vecchione A, Gottardo F, Gomella LG, Wildemore B, Fassan $\mathrm{M}$, et al. Molecular genetics of prostate cancer: clinical translational opportunities. J Exp Clin Cancer Res 2007; 26: 25-37.

29 Bowen C, Bubendorf L, Voeller HJ, Slack R, Willi N, et al. Loss of NKX3.1 expression in human prostate cancers correlates with tumor progression. Cancer Res 2000; 60: 6111-5.

30 McNeal JE. Origin and evolution of benign prostatic enlargement. Invest Urol 1978; 15: 340-5.

31 De Marzo AM, Marchi VL, Epstein JI, Nelson WG. Proliferative inflammatory atrophy of the prostate: implications for prostatic carcinogenesis. Am J Pathol 1999; 155: 1985-92.

32 Bussemakers MJ, van Bokhoven A, Verhaegh GW, Smit FP, Karthaus HF, et al. DD3: a new prostate-specific gene, highly overexpressed in prostate cancer. Cancer Res 1999; 59: 5975-9.

33 Hessels D, Klein Gunnewiek JM, van Oort I, Karthaus HF, van Leenders GJ, et al. DD3PCA3-based molecular urine analysis for the diagnosis of prostate cancer. Eur Urol 2003; 44: 8-16.

34 Gen-Probe Incorporated data on file. 2007. Available at http:// www.pca3.org/pro/pca3-utility.
35 Haese A, Van Poppel H, Marberger M, Mulders P, Abbou CC, et al. The value of the PCA3 assay in guiding decision which men with a negative prostate biopsy need immediate repeat biopsy: preliminary European data. Eur Urol 2007; 6 (Suppl): 48 (Abstract 101).

36 Whitman EJ, Groskopf J, Ali A, Chen Y, Blase A, et al. PCA3 score before radical prostatectomy predicts extracapsular extension and tumor volume. J Urol 2008; 180: 1975-8; discussion 1978-9.

37 Horoszewicz JS, Kawinski E, Murphy GP. Monoclonal antibodies to a new antigenic marker in epithelial prostatic cells and serum of prostatic cancer patients. Anticancer Res 1987; 7: 927-35.

38 Hara N, Kasahara T, Kawasaki T, Bilim V, Obara K, et al. Reverse transcription-polymerase chain reaction detection of prostate-specific antigen, prostate-specific membrane antigen and prostate stem cell antigen in one milliliter of peripheral blood: value for the staging of prostate cancer. Clin Cancer Res 2002; 8: 1794-9.

39 Isaacs W, De Marzo A, Nelson WG. Focus on prostate cancer. Cancer Cell $2002 ; 2$ : 113-6.

40 Bauer JJ, Sesterhenn IA, Mostofi KF, McLeod DG, Srivastava $\mathrm{S}$, et al. p53 nuclear protein expression is an independent prognostic marker in clinically localized prostate cancer patients undergoing radical prostatectomy. Clin Cancer Res 1995; 1: 1295-300.

41 Malins DC, Johnson PM, Barker EA, Polissar NL, Wheeler TM, et al. Cancer-related changes in prostate DNA as men age and early identification of metastasis in primary prostate tumors. Proc Natl Acad Sci USA 2003; 100: 5401-6.

42 Carpten J, Nupponen N, Isaacs S, Sood R, Robbins C, et al. Germline mutations in the ribonuclease $\mathrm{L}$ gene in families showing linkage with HPC1. Nat Genet 2002; 30: 181-4.

43 Wagenlehner FM, Elkahwaji JE, Algaba F, Bjerklund-Johansen $\mathrm{T}$, Naber KG, et al. The role of inflammation and infection in the pathogenesis of prostate carcinoma. BJU Int 2007; 100: 733-7.

44 Casey G, Neville PJ, Plummer SJ, Xiang Y, Krumroy LM, et al. RNASEL Arg462Gln variant is implicated in up to $13 \%$ of prostate cancer cases. Nat Genet 2002; 32: 581-3.

45 Salm SN, Burger PE, Coetzee S, Goto K, Moscatelli D, et al. TGF-\{beta $\}$ maintains dormancy of prostatic stem cells in the proximal region of ducts. J Cell Biol 2005; 170: 81-90.

46 Cerveira N, Ribeiro FR, Peixoto A, Costa V, Henrique R, et al. TMPRSS2-ERG gene fusion causing ERG overexpression precedes chromosome copy number changes in prostate carcinomas and paired HGPIN lesions. Neoplasia 2006; 8: 826-32.

47 Jhavar SG, Fisher C, Jackson A, Reinsberg SA, Dennis N, et al. Processing of radical prostatectomy specimens for correlation of data from histopathological, molecular biological and radiological studies: a new whole organ technique. J Clin Pathol 2005; 58: 504-8.

48 Hoque MO, Topaloglu O, Begum S, Henrique R, Rosenbaum E, et al. Quantitative methylation-specific polymerase chain reaction gene patterns in urine sediment distinguish prostate cancer patients from control subjects. J Clin Oncol 2005; 23: 6569-75.

49 Eeles RA. Genetic predisposition to prostate cancer. Prostate Cancer Prostatic Dis 1999; 2: 9-15.

50 Ostrander EA, Johannesson B. Prostate cancer susceptibility loci: finding the genes. Adv Exp Med Biol 2008; 617: 179-90. 
51 Rennert H, Bercovich D, Hubert A, Abeliovich D, Rozovsky U, et al. A novel founder mutation in the RNASEL gene, 471deIAAAG, is associated with prostate cancer in Ashkenazi Jews. Am J Hum Genet 2002; 71: 981-4.

52 Steinberg GD, Carter BS, Beaty TH, Childs B, Walsh PC. Family history and the risk of prostate cancer. Prostate 1990; 17 337-47.

53 Emmert-Buck MR, Vocke CD, Pozzatti RO, Duray PH, Jennings SB, et al. Allelic loss on chromosome 8p12-21 in microdissected prostatic intraepithelial neoplasia. Cancer Res 1995; 55: 2959-62

54 Urisman A, Molinaro RJ, Fischer N, Plummer SJ, Casey G. Identification of a novel Gammaretrovirus in prostate tumors of patients homozygous for R462Q RNASEL variant. PLoS Pathog. 2006; 2: e25.

55 Kommu S, Sharifi R, Eeles RA. The proteomic approach to urological biomarkers. BJU Int 2004; 94: 1215-6.

56 Petricoin EF 3rd, Ornstein DK, Paweletz CP, Ardekani A, Hackett PS, et al. Serum proteomic patterns for detection of prostate cancer. J Natl Cancer Inst 2002; 94: 1576-8.

57 Ornstein DK, Rayford W, Fusaro VA, Conrads TP, Ross SJ, et al. Serum proteomic profiling can discriminate prostate cancer from benign prostates in men with total prostate-specific antigen levels between 2.5 and $15.0 \mathrm{ng} / \mathrm{mL}$. J Urol 2004; 172: 1302-5.

58 Girinsky T, Koumenis C, Graeber TG, Peehl DM, Giaccia AJ. Attenuated response of $\mathrm{p} 53$ and $\mathrm{p} 21$ in primary cultures of human prostatic epithelial cells exposed to DNA-damaging agents. Cancer Res 1995; 55: 3726-31.

59 Kiviharju-af Hällström TM, Jäämaa S, Mönkkönen M, Peltonen K, Andersson LC, et al. Human prostate epithelium lacks Wee1A-mediated DNA damage-induced checkpoint enforcement. Proc Natl Acad Sci USA 2007; 104: 7211-6.

60 Chan N, Milosevic M, Bristow RG. Tumor hypoxia, DNA repair and prostate cancer progression: new targets and new therapies. Future Oncol 2007; 3: 329-41.

61 De Marzo AM, Putzi MJ, Nelson WG. New concepts in the pathology of prostatic epithelial carcinogenesis. Urology 2001 57: $103-14$.
62 Shah R, Mucci NR, Amin A, Macoska JA, Rubin MA. Postatrophic hyperplasia of the prostate gland: neoplastic precursor or innocent bystander? Am J Pathol 2001; 158: 1767-73.

63 Roberts RO, Bergstralh EJ, Bass SE, Lieber MM, Jacobsen SJ. Prostatitis as a risk factor for prostate cancer. Epidemiology 2004; 15: 93-9.

64 Krieger JN, Riley DE, Vesella RL, Miner DC, Ross SO, et al. Bacterial dna sequences in prostate tissue from patients with prostate cancer and chronic prostatitis. J Urol 2000; 164: 1221-8.

65 Adhami VM, Malik A, Zaman N, Sarfaraz S, Siddiqui IA, et al. Combined inhibitory effects of green tea polyphenols and selective cyclooxygenase- 2 inhibitors on the growth of human prostate cancer cells both in vitro and in vivo. Clin Cancer Res 2007; 13: 1611-9.

66 Till JE, McCulloch EA. A direct measurement of the radiation sensitivity of normal mouse bone marrow cells. Radiat Res 1961; 14: 213-22.

67 Bonnet D, Dick JE. Human acute myeloid leukemia is organized as a hierarchy that originates from a primitive hematopoietic cell. Nat Med 1997; 3: 730-7.

68 Guzman ML, Swiderski CF, Howard DS, Grimes BA, Ross RM, et al.. Preferential induction of apoptosis for primary human leukemic stem cells. Proc Natl Acad Sci USA. 2002; 99: $16220-5$.

69 Collins AT, Berry PA, Hyde C, Stower MJ, Maitland NJ. Prospective identification of tumorigenic prostate cancer stem cells. Cancer Res 2005; 65: 10946-51.

70 Litvinov IV, Vander Griend DJ, Xu Y, Antony L, Dalrymple $\mathrm{SL}$, et al. Low-calcium serum-free defined medium selects for growth of normal prostatic epithelial stem cells. Cancer Res 2006; 66: 8598-607.

71 Masters JR, Kane C, Yamamoto H, Ahmed A. Prostate cancer stem cell therapy: hype or hope? Prostate Cancer Prostatic Dis 22 April 2008 [Epub ahead of print].

72 Figueiredo ML, Kao C, Wu L. Advances in preclinical investigation of prostate cancer gene therapy. Mol Ther 2007; 15 1053-64. 